\title{
Roles of Rural Women in Livelihood and Sustainable Food Security in Ethiopia: A Case Study from Delanta Dawunt District, North Wollo Zone
}

\author{
Nahusenay A. ${ }^{1, *}$, Tessfaye T. ${ }^{2}$ \\ ${ }^{1}$ Department of Geography and Environmental Sciences, College of Social Sciences and Humanity, Samara University, Ethiopia \\ ${ }^{2}$ Department of Geography and Environmental Studies, College of Social Sciences and Humanity, Addis Ababa University, Ethiopia
}

Email address:

nahugeta@gmail.com (Nahusenay A.)

\section{To cite this article:}

Nahusenay A. and Tessfaye T.. Roles of Rural Women in Livelihood and Sustainable Food Security in Ethiopia: A Case Study from Delanta Dawunt District, North Wollo Zone. International Journal of Nutrition and Food Sciences. Vol. 4, No. 3, 2015, pp. 343-355.

doi: 10.11648/j.ijnfs.20150403.22

\begin{abstract}
This study was conducted at Delanta Dawunt District, which was characterized by high population density, recurrent drought and food insecurity. By so doing, it has assessed the various ranges of activities that are performed by women and identified the overall problems encountered by women. To these end, attempts have been made by rural women to identify their roles in livelihood and sustainable food security in Ethiopia in general and the Delanta Dawunt District in particular. The study was conducted by taking four sampled rural local districts from a total of 44 local districts. Household surveys were made by taking 160 women and 40 men. The interviewees were selected using stratified random sampling technique in 50 households from each local district. The data were analyzed using percentage, mean score, cumulative frequency and Chi-Square tests. As the results shown, women were more participating in a wide range of poverty alleviation. They were food producers and providers in Delanta Dawunt District. Despite their fundamental roles in agricultural sectors and sustainable food security, women have been marginalized for so long. Among the total respondents, about 85, 80, 71 and $54 \%$ of the respondents stated that women were more venerable for quality and quantity of food, water, health services and fuel wood, respectively and $65 \%$ of adults (women) ate twice per day (mornings and evenings). This occurred under the normal and good harvesting seasons. In terms of agro-ecology, two meals per day were more common in Woina Dega (72\%), Dega (70\%) and Kolla (46\%). In general, women have limited access of dietary composition of nutritional meals in the study area. Among the crop production activities, storage preparation $(92 \%)$ and storing processes $(83 \%)$ were mainly performed by women, weeding, harvesting and post-harvesting, and threshing field preparation tasks shared equally with men by 53,50 and $83 \%$, respectively. With respect to livestock management, women have taken a lion's share. Of the livestock management tasks, milk processing $83 \%$ ), caring of new borne animals (52\%) and barn cleaning (63\%), and almost all the household duties were predominantly performed by women. Women have also limited access of agricultural products, credit facilities, skill training, education, extension services and information. To strengthen and develop women involvement in livelihood and sustainable food security all concerned bodies should take appropriate measures to empower women's in education and training. The packages of development including improvements in income, health, nutrition and education should be addressed women's.
\end{abstract}

Keywords: Food Security; Livelihood; Local District; Poverty Alleviation; Sustainable

\section{Introduction and Background of the Study}

Women are both producers and providers of food in developing countries, most particularly in African countries. Apart from participating in a wide range of productive activities, they are also carrying out full responsibility not only in bearing and caring children but also in nurturing and breast-feeding them after birth. How can their contributions be measured relative to other members of the family? This study is designed to address a number of issues related to the conceptualization, collection, and interpretation of indicators of the sexual division of labor; the social, political and economic status of women relative to men; and women's agricultural task participation and their role in the attainment 
of sustainable food security in Ethiopia in general and the study area in particular.

\subsection{Statement of the Problem}

The population of the world is dependent on land resources to extract food and other necessities. As some estimates indicate, more than $97 \%$ of the total food supply for the world's population is derived from land and the remaining 3\% from aquatic resources [1]. For these activities to happen, the main actors are undoubtedly women. Ironically, the perception of women's status in most countries is low and affected by numerous practices that are often based on taboos, superstitions and misinterpretations of religious tenets, which continue to have strong effect on their development, assertiveness and participation in life around them. These beliefs have also affected the economic, social and political role of women in the society [2].

According to the UN [3] estimates, global population is increasing from time to time. In the mid-19thcentury, it was about 1 billion; between 1918 and 1927, it reached 2 billion; and between 1974 and 1987 about 4 to 5 billion, respectively. At the dawn of the twenty-first century, it reached over 6 billion. It is estimated to surpass the 8 billion mark by the year 2025 [4]. This means that more food is needed. The ecosystem is rapidly collapsing around us; millions of people are dying of hunger, disease and war; nation states, communities and families are breaking apart, turning more and more people into migrants and refugees; and the ignorance, greed and hatred in our minds are aggravating fear and insecurity, damaging all our relationships $[5 ; 6]$.

The natural, climatic, man-made and other environmental disturbances like the greenhouse effect, global warming, acid rain and ozone depletion, drought, earthquake, flood and war, pose major threats to human and planetary health. According to Bandarage [4], about 4 million hectares of rain-fed croplands are lost due to soil erosion and as much as 7 million hectares of farmland are abandoned due to salinization, desertification, paving and other forms of environmental degradation. Like the physical environment, much of humanity is also faced with a crisis of survival. The world is said to be experiencing the worst unemployment crisis, relative and absolute poverty lacking essentials of life such as basic health care, sanitation, safe water, education [7]. Everywhere, women and children are suffering more than others due to the combined effects of environmental destruction, poverty and traditional cultural practices. Destruction of forest and land, unemployment, low wages and increasingly limited access to other resources make it difficult for women to feed themselves and their families [8]. Men, women and children in rural households engage in a variety of off-farm activities throughout the year. Women's contributions to total household incomes are by no means negligible. Women who help in the family farm without remunerations are classified as housewives. Furthermore, such a classification testifies to our stereotypical image of the married women [9].

Although women invented agriculture based on their knowledge about gathering, with technological advancement farming became predominantly a male vocation. Despite the fact that women's contribution to cultivation and craft production continued to be essential, they came to be seen primarily as the producers of children [4]. Women are more vulnerable to the life stresses associated with parenthood than men, because they are assigned primary responsibility for childbearing and are given little support from society to make their job easier [10].

As per FAO has defined food security not only in terms of access to, and availability of food, but also in terms of resource distribution to produce food and purchasing power to buy food, where it is produced [11]. This implies that food security is a broad concept dealing with production, distribution and consumption vis-à-vis food entitlement for all household members. According to UN [3] report, 'Human Development Report,' there is no country in the world in which women's quality of life is equal to that of men. According to FAO [8] reported, it is estimated that $20 \%$ of the world's population suffers from hunger and, at the extreme; 800 million of them endure chronic malnutrition. The problem of food insecurity is evidently seen as 88 countries, nearly half of which are situated in Sub-Saharan Africa, where over 100 million people suffer from hunger. More than half of the continent's food insecure population lives in Ethiopia and other six African countries, namely Chad, Democratic Republic Congo, Uganda, Mozambique, Zambia, and Somalia. They account for over $40 \%$ of the population in Africa [12].

According to the complex measures that include among others longevity, health status, educational opportunities, employment, political powers and property rights, women are always disadvantaged. This paper would hence briefly assess the rural Ethiopian women's crucial roles in agro-economic development both as food producers and providers and as promoters of sustainable food security and livelihood in the country at large and the family in particular. Besides, this study deals about some of the major problems that women face while promoting agricultural activities due to their subordinate position in rural Ethiopia in general and the study area in particular.

\subsection{Objectives of the Study}

The general objective of the study was to assess the overall roles and contributions of women in socio-economic development and understand the constraints to their empowerment. In line with the general objective, the specific objectives of the study would hence be as follows:

Assess the ranges of activities that are performed by women;

Examine the overall problems encountered by women such as subordinations; and

Evaluate women's access to productive resources;

\subsection{Research Questions}

To achieve these objectives, the manuscript outlined the 
following research questions.

What are the major roles of women in sustainable food security and agricultural activities?

Why are women subordinated in economic spheres?

What are the impediments of women's participation in the development process?

\subsection{Data Types, Sources and Sampling Techniques}

The data inputs for the study are derived from both primary and secondary sources.

\subsubsection{Data Types and Sources}

The primary data for this study was generated through household surveys by employing different methods. This was accomplished by conducting formal interviews and discussions with rural women, men, the heads of women affairs and other concerned authorities. For this purpose, similar questionnaires were developed and provided to all groups of samples. The main data gathering tool for this study was structured interview questionnaires and field observations. Most of the items in this instrument were close-ended. Some open-ended questions were also included for the advantage to obtain qualitative information on the attitudes, beliefs, and practices of the people in general and women in particular. Secondary data from both published and unpublished documents of governmental and nongovernmental organizations was also extracted to supplement and /or strengthen the primary data. Historical, cultural, socio-economic backgrounds to the study area were also obtained by using secondary materials.

\subsubsection{Pilot Test and Data Collection Procedure}

Pilot test was administered by taking three men and seven women in Angolena-Terena District of North Shewa Administrative Zone in Amhara Region. The purpose of this test was to check the appropriateness of the items in the instrument and to make necessary correction based on the feedbacks obtained from the respondents. Based on the pretest results, some improvements were made in preparing the final questionnaire. Finally, 200 copies of the questionnaires were distributed to the sampled respondents. All of the questionnaires were filled in and collected.

\subsubsection{Sampling Techniques}

The target population of the study was rural women and men. The sample size was 200 rural households of which 160 were women and to know the attitudes of men towards women's work 40 men were taken. Among the 44 local districts that are found in Delanta Dawunt District, the survey was undertaken in four of them (Table 1). One of the motives of the survey was to study variation in the patterns of production, consumption, and coping mechanisms that affect food security and livelihood based on agro-ecological variations. To this end, four local districts (rural districts) were selected based on the above stated variations. The total populations of the four local districts are approximately equal and similar. To make the study manageable, a sample of 50 households was taken from each rural district by using simple stratified random sampling techniques. This technique is used to determine the sample size of each kebele and the sample size of women and men after the districts have been selected. The respondents were interviewed at various places and times. Since the local districts are found in different directions around the District town (Wegeltena). The interview conducted on different local districts and agroclimatic zones (Table 1).

Table 1. Study local peasant associations.

\begin{tabular}{l|ll}
\hline Site name & NRP* & Agro-ecological zone \\
\hline $\begin{array}{l}\text { Goshmeda } \\
\text { Mekelet }\end{array}$ & 50 & Kolla $($ Lowland $<2100 \mathrm{~m})$ \\
$\begin{array}{l}\text { Chekutir- } \\
\text { Kechinareh }\end{array}$ & 50 & Dega $($ Highland $>2700 \mathrm{~m})$ \\
Chet-Yabtie & 50 & Woina Dega $($ Midland b/n 2100 and $2700 \mathrm{~m})$ \\
Total & 200 & \\
\hline
\end{tabular}

Source: Based on Field Survey; NRP= Number of Respondents

\subsection{Method of Data Analysis}

The primary data have been analyzed and presented by using both descriptive and inferential statistical techniques. The former include percentage, cumulative frequency, standard deviation, and tables, while the latter Chi-Square tests. The Chi-Square test was employed to see the association or homogeneity between the agro-ecological zones with reference to responses regarding family planning uses, agricultural works, dietary meal composition, and coping strategies used by peasants during famine (scarcity of food) and its impacts.

\subsection{Significance of the Study}

The findings of the research will have theoretical as well as practical significance. The major role of this study is to investigate the problems and then come up with possible solutions. The result of this study will have the following significance.

Provide information for Women Affairs Office, policy designers, program planners, governmental bodies and other concerned authorities on how to improve women's status on resource utilization and decision-making.

Indicate the negative effect of women's marginalization /subordination on development, economic growth and poverty alleviation in the study region.

Help governmental and non-governmental organizations to be gender-sensitive while promulgating policies.

Put forward suggestions to the government and other concerned organizations as well as the population to consider the integration of women into the production activities by giving them equal status and power in the economic development process.

Suggest to concerned bodies to develop the educational capacities and health conditions of women so as to make them more fruitful in their life and the society. 


\subsection{Organization of the Study}

The study is organized as follows: following the introductory part that is discussed above indicating backgrounds, objectives, research questions, data types and sources, sampling techniques, methodology of the study, and significances, the second chapter would review the relevant literature. It addresses the role of rural women in livelihood and food security, agricultural activities, and women's position in economic production and labor force participation; access to resources and utilizations, and legal rights and participation in decision-making in the household and community. The third chapter would make a brief description of the study area, while the fourth chapter interprets the results of the study: focusing on women's role in family planning, agricultural activities, coping mechanisms during food scarcity, natural resource management, division of labor and decision-making power. The final chapter would present summary, conclusions and recommendations.

\section{Location, Size and Demographical Characteristics of the Study Area}

\subsection{Geographical Location of Delanta Dawunt District}

The physical aspects of Delanta Dawunt District include the location and size, topography, vis-à-vis climate, soil, water, land use and land cover systems. The social/human aspects contain population, religious and cultural institutions, social services. All these will be discussed in the following subsections.

\subsubsection{Geographical Location and Size of the Area}

Delanta Dawunt District is one of the nine Districts of North Wollo Zone, which is situated in the western part of the zone. It is located between $11^{\circ} 30^{\prime} 17^{\prime \prime} \mathrm{N}$ latitudes and $39^{\circ} 09^{\prime 2} 23$ " E longitudes with $499 \mathrm{kms}$ away to north of Addis Ababa and $98 \mathrm{kms}$ to northwest of Dessie town. The District is bordered by Mekdella, Tenta and Ambassel Districts in the south and southeast; Gubalafto District in the east; Wadla District in the north and northwest; and Tach-gayit District of South Gonder Zone in the west (figure 1). Moreover, Delanta Dawunt is surrounded by the headwater tributaries of the Blue Nile, such as Beshilo and Zhita rivers. These rivers flow under very steep slope gradient in gorges and of V-shape valleys.

\subsubsection{Topography of the Study Area}

The major landforms of Delanta Dawunt District comprise extensive plateaus, chains of hills with mountainous ridge, river-valleys and very deep gorges at the boundary. Almost it is oval in shape with dendritic drainage pattern, steep ridges, and numerous convex hills at the plain area and gorges at the boundary. About two-third of the area, embracing altitude ranges from 2100-3500 masl, is highly populated. The remaining one-third of the District is located mainly along the river valleys on east (Terry River), southeast (Beshilo River), and north and northwest (Zhita River) location which range from 1500-2100 $\mathrm{m}$. All of them are the Abay River tributaries. Topography of the highland plateaus especially, those are elevated above 3000 meters are dominated by hills. According to WAOR[13], the general classification of the area is about $30 \%$ mountainous, $30 \%$ plains, $36.5 \%$ gorges and $3.5 \%$ other land features. The lowland (Kolla) areas whose altitude ranges between 1500 to 2100 masl, covers $29.8 \%$ of the District. The midland, vis-à-vis Woina Dega, whose altitude ranges between 2100 to 2700 masl has $43.8 \%$ coverage and the rest $(26.4 \%)$ covers by highlands (Dega) whose altitude is above 2700 masl. Generally speaking, the topography of the District is $30 \%$ mountainous, $35.5 \%$ plains, and $36.5 \%$ gorges.

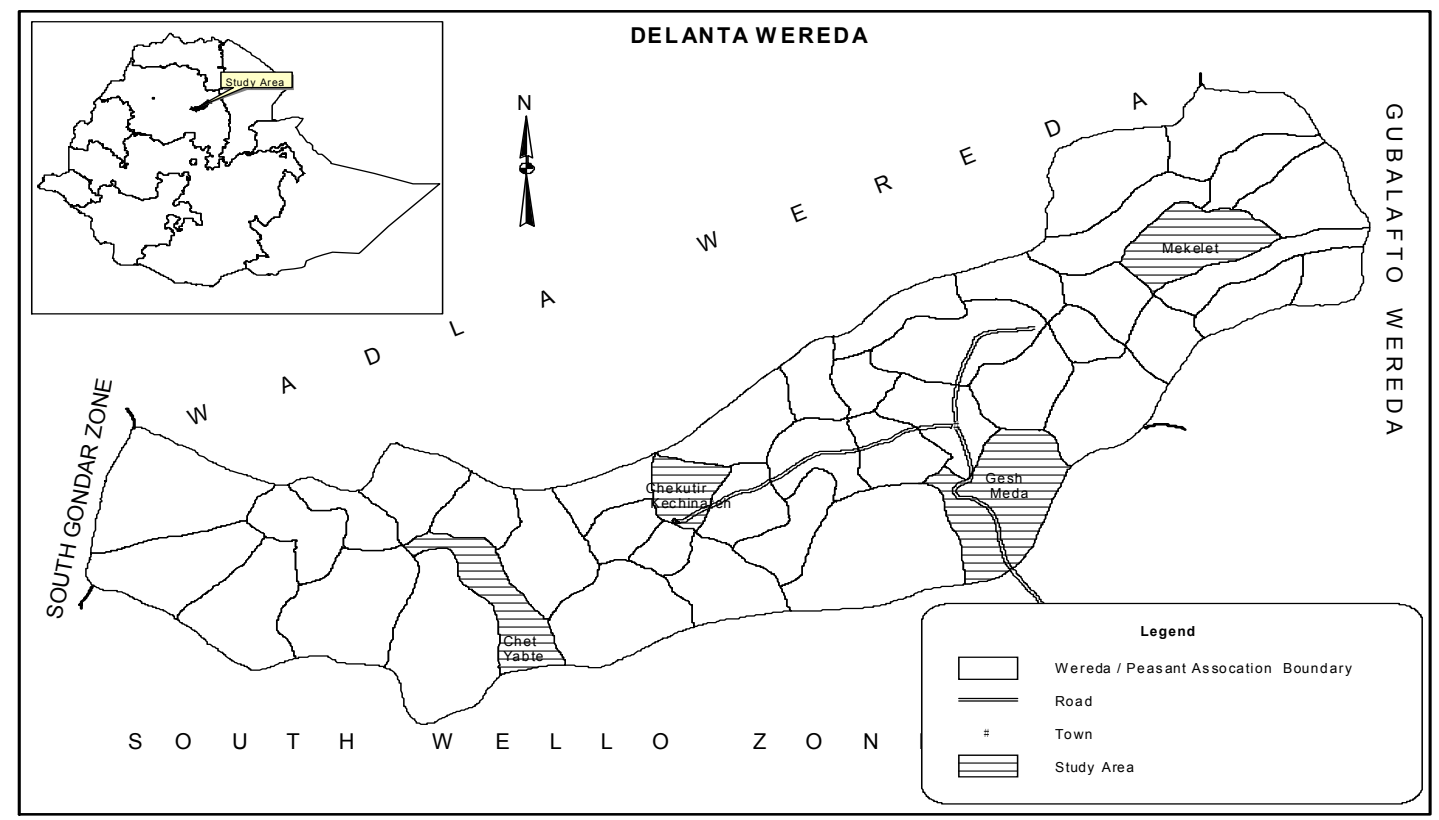

Figure 1. Location map of the study area. 


\subsubsection{Climate of the Study Area}

The traditional agro-climatic zonation/classification of Ethiopia, which is categorized into four major zones based on altitude which are Kolla, Woina Dega, Dega and Wurch. As per the traditional agro-climate classification, the study area falls in all of the categories that basically correlated with elevation (Table 2).

The climate of the area is characterized by dry seasons (from October to February cold-dry and March to June hotdry) and wet season (from mid-June to September). The rainfall pattern is monomodal with peak periods from midJuly to early September. The mean annual rainfall is about $812 \mathrm{~mm}$ of which $75-80 \%$ is received in summer (Kiremt) and $25-20 \%$ in the spring (Belg) seasons. The mean annual minimum and maximum temperatures are 6.8 and $19.6^{\circ} \mathrm{C}$, respectively (Figure 2). Peoples in the upper topographic position, their agricultural work primarily depend on spring (Belg) rains, whereas the middle and lower topographic positions are both the Kiremt and Belg rains. As a result, the small, erratic and unreliable rainfall, the area is prone to sporadic droughts.

\subsubsection{Geology and Soils of the Study Area}

Geology of the study area is characterized by the trap series of tertiary periods, similar to much of the central Ethiopian highlands [15]. According to Dereje et al. [16] reported the area covered by Oligocene rhyolite and very thick ignimbrite units encompassing predominantly of alkaline basalt with numerous inter-bedded flow of trachyte. The granite, gneisses and basalt rock types exist in the area forming part of the basement complex and most of the soils are basaltic parent material.

Soils of the study area are greatly influenced by topography with high surface runoff during the main rainy season. There was no scientific studies in the area until this study was conducted except for FAO/UNDP [17] general soil survey (1:1 000000 scales) at the national level. The local people are called the soils namely by Walka or Mererie Afer or TikurAfer (Vertisols) in the plain area and Nechatie or Gracha Afer (Cambisols) and (Leptosols) in steep slope or mountainous area.

Table 2. Traditional agro-ecological zones (ACZ) of the Northern Ethiopian highlands.

\begin{tabular}{lllll}
\hline Traditional ACZ & Kolla & $\begin{array}{l}\text { Woina } \\
\text { Dega }\end{array}$ & Dega & Wurch \\
\hline Elevation $(\mathrm{m})$ & $1500-1800$ & $1800-2400$ & $2400-3500$ & $>3500$ \\
Temperature $\left({ }^{\circ} \mathrm{C}\right)$ & $18-20$ & $15-18$ & $10-15$ & $<10$ \\
Rainfall $(\mathrm{mm})$ & $300-900$ & $500-1500$ & $700-1700$ & $>900$ \\
Dominant crop & $\begin{array}{l}\text { Sorghum, } \\
\text { maize }\end{array}$ & $\begin{array}{l}\text { teff, maize, } \\
\text { wheat }\end{array}$ & $\begin{array}{l}\text { Barley, } \\
\text { wheat }\end{array}$ & Barley \\
\hline
\end{tabular}

Source: Adapted from Getahun [14].

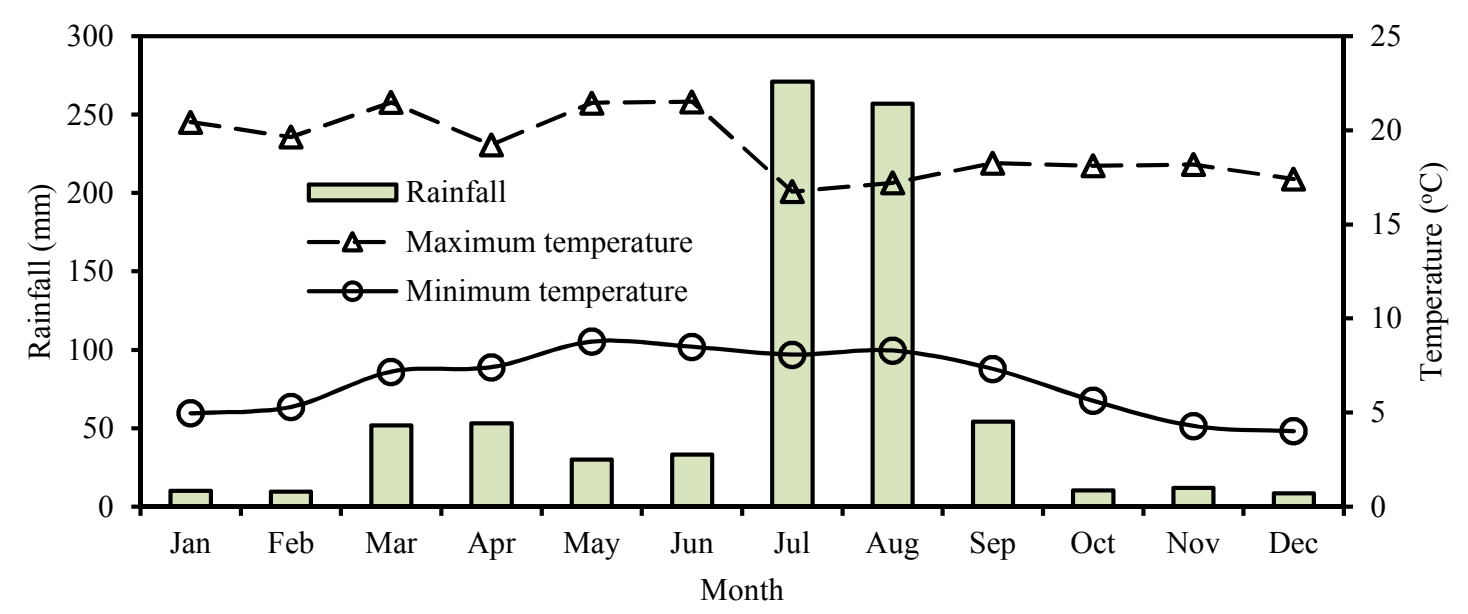

Figure 2. Mean monthly rainfall, maximum and minimum temperatures of the study area.

\subsubsection{Water Resources}

According to Calow et al cited in Stephen [24], in the northern highlands of Ethiopia many communities suffer water stress on a seasonal and annual basis mainly due to lack of availability and access. However, social conflicts have never accompanied water use in Ethiopia as has been the case in the countries of the Middle East. This could be attributed to the fact that the water resources in Delanta Dawunt which are inter-communal rather than being international. The major constraints identified in Delanta Dawunt District are water quality and distance problems. Water supports the ecosystem, livelihood and food security. There are no enough surface water resources in the District, both in terms of quantity and quality. People said that water quality becomes worse from June to August (during the main rainy seasons) when rivers and springs experience over-bank full discharge. Ironically, this is also the period when the volume of water is the highest.

The distance needed to get to the nearest spring has been presented as another limitation. Villagers in Delanta Dawunt collect most of their water from springs and use the water for household utilities, small animals (calves) and seedlings (young plants). The year-round water supply is limited to the 
few rivers that flow in deep gorges and the few scattered springs found on the top of plateaus. Women and children are responsible for carrying water, which is reported to be one of the most time-consuming and labor-intensive task. At the time of this study, the international non-governmental organization, viz. Oxfam Great Britain, has developed more than 60 water points that could serve nearly 19700 people. The issue that still needs attention is 'water marketing'. In few place, it has been observed that people sold their labor to collect water for others. The extent of this practice in Delanta Dawunt is yet unknown, but evidently water has an economic price related to the prevailing wage labor rates.

\subsubsection{Land Use Systems and Their Coverage}

Land is the principal resource for human beings in general and agrarian societies in particular. According to the WHOR [20], the total areal size of the District is estimated to be 147,829 hectares. The average land holding per household is estimated to be 1 hectare $(0.75$ hectare for crop production and 0.25 hectare for grazing) (Table 3 ). The land uses are both private (farming) and communal (grazing land) land holdings which can be identified through land use patterns. Cultivated and grazing lands are the major land use types in the area which accounts for $21.6 \%$ and $8.2 \%$, respectively. Among the total area, the largest proportion (45\%) of the land is currently unutilized and the remaining $(25.2 \%)$ is covered by shrub/bush and natural and plantation forests. Agriculture is the predominant economic sector which was over $95 \%$ of the population engaged in this sector [13]. The farming system is mixed both livestock and crop production which was characterized by subsistence methods. The overall farming system was strongly oriented towards grain production to sustain farmers' livelihoods and it practiced using oxen and horses for land ploughing and grains threshing. Crop residues and intensive grazing were major livestock feed resources in the area.

The common rainfed crops grown in the area are bread wheat (Triticum aestivum L.), food barley (Hordeum vulgare L.), faba bean (Vicia faba L.), lentil (Lens culinaris L.), grass pea (Lathyrus sativus L.), chickpea (Cicer arietinum L.) teff (Eragrostis tef L.) and sorghum (Sorghum bicolor (L.) Moench. All these crops are managed using traditional agricultural techniques and equipment. Moreover, few types of vegetables, fruits, root crops and spices are also produced. Most of the arable land is under rainfed farming while very small area is irrigated at the valley bottom or around riverbanks to produce vegetables and fruits [13].

Table 3. Estimated land use pattern of Delanta Dawunt District.

\begin{tabular}{lll}
\hline Land Use Pattern & Hectare & Percent \\
\hline Cultivated land (crop land) & 31,151 & 21 \\
Grazing land (Pasture land) & 12,058 & 8.2 \\
Shrub/Bush land & 37,255 & 25.2 \\
Unutilized and wasteland & 67,365 & 45.6 \\
Total & 147,829 & 100 \\
\hline
\end{tabular}

Source: WAO and Natural Resource Development Department Office [13]

\subsection{Human Characteristics of Delanta Dawunt District}

The human characteristics include population, religious and social institution, namely Kire/Idir, Senbete, Tsiwa Mahiber and Iqqub. All these can be discussed in the coming subsections.

\subsubsection{Population}

As per CSA [18] reported, the population of Delanta Dawunt District was 177 463, with an average family size of five. The rural population constituted 96.5, males 51 and females $49 \%$ of the total population in the district. The District is divided into 44 local districts that are stretched into different agro-ecological zones. Delanta Dawunt District is one of the four poorest, highly inaccessible and seriously drought prone Districts of the Amhara region. The people of Delanta Dawunt do not generally produce food for yearround consumption even in a year considered to be normal climatically. This is due to over population, severe land degradation, land shortage and erratic rainfall.

\subsubsection{Religious and Social Institutional Structures}

People in the Delanta Dawunt District live in villages that are clustered and dispersed. The houses are dominantly thatch-roofed. Some in the highlands have stonewalls, but most are built from mud and wood walls, thatch-roofed and without any internal toilet and kitchen facilities. Nuclear and extended families make up most of the villages in Delanta Dawunt District. They provide a social network in times of need and during celebrations, like weddings and religious feast days. All of the families in the survey District belong to the Amhara ethnic group and speak Amharic language only.

Orthodox Christianity and Islam are the two most widely practiced religions in Delanta Dawunt. According to CSA [18] reported, over $89 \%$ of the families in Delanta Dawunt District are the Orthodox Tewahido Christians and 11\% Muslims. The Dega and Woina Dega areas are totally inhabited by the Orthodox Tewahido Christians; the Kolla areas are inhabited by both the Muslim and Orthodox Tewahido Christians.

The traditional institutional structures, namely Kire/Idir, Senbete, Tsiwa-mahiber and Iqqub, exist in the area. The Kire is confined to 'Gots' (Villages) level. Its function is mainly on social matters. It mobilizes and governs society in case of death of a member and his/her families, and wedding ceremony. It also serves as social court and judge, based on it under customary laws, in case of hidden damage on some body's properties or life. There is no any discrimination of his/her socio-economic stratum and religious; any household head can be member of a 'Kire'.

The role of 'Tsiwa-mahiber' and 'Senbete' is for celebration of a given holiday named by a specific saintwhich are mainly practiced by the Orthodox Tewahido Christians. The 'mahiber' members provide labor support to their members in case of illness and death. Moreover, they also contribute money in case of death of a member and member's family. Both of them institutions are commonly understood as an organization based on Christian religious beliefs and one that 
facilitates worship. It is used as a forum for resolving conflicts and strengthening spiritual attachments to the church as well as the social services.

\subsubsection{Social Services}

Delanta Dawunt was very remote District. Even its capital, Wegeltena, was accessible via a dry weather road from Dessie which took about 6-7 hrs. to reach the capital. There was no other road except some feeder roads that had been constructed by food for work and employment generation schemes programs. These feeder roads used to reach Dawunt in the west and Terefe in the northeast parts of the District, which were hardly used by the private vehicles. During this study, there was one new road under construction that crosses through the District from North Shewa to Sekota (Wag Humra Zone). Due to the absence of bridges on the rivers, it was closed for more than three months during the rainy seasons including the spring (belg) seasons. Delanta Dawunt District had also lacks for modern means of communication vis-à-vis mobile, radio, telephone, postal service, bank, electricity and credit services. There was only one manual telephone service, which interrupted its function frequently due to technical problems and shortage of labor. The only means of communication in the District was the periodical marketing days. The people met and exchanged messages and commodities during the market day. There had four major ('big') marketing and nine minimarketing days and places in the District.

Education is one part of social infrastructure. It is an umbrella for social, political, economic and cultural heritage. As per the WEOR [19] indicated that there were 34 primary and junior secondary schools for 44 local districts, one high school, one adult (Community Skill Training Center) and one Kindergarten. In terms of health services, the District has one health center, 8 clinics and 5 health posts [20]. As the shortage of health facilities, the population of the District

suffers from different types of diseases, most notably water born diseases, scarbies, and diarrhea and eye disease.

\section{Results and Discussion}

\subsection{Role of Rural Women in Livelihood and Sustainable Food Security}

Sustainable food security and livelihood might be achieved by various means among which the main components are the close integration of crop production and livestock raising, agricultural and non-agricultural activities and incomes. Women were responsible for providing certain foods to the household members. They provided these foods by either producing them in their separate fields, gardens or livestock concerns or by selling and/or exchanging some of their produce to obtain the foods they need. These can be discussed in the following sub section subsequently. The rural development of Ethiopia that is based on growth with equity will require the full integration of women [21]. The vast majorities of Ethiopian women (89\%) live in rural areas and work in the informal agricultural sector [22; 23]. It is characterized by ease of entry, reliance on local resources; family ownership, small-scale entrepreneurship, labor intensity and need of simple skills obtained outside the formal educational system. Participation of women was growing in this informal sector. The workloads and the responsibilities of women have increased. They were not only responsible for the daily requirement and family care but also provided the labor for agricultural production, animal husbandry, storing and marketing agricultural products, and purchasing home apparatus.

\subsubsection{Nutrition and Composition of Meals}

Table 4. Frequency of meals per day by agro-ecological zones (AEZ).

\begin{tabular}{|c|c|c|c|c|c|c|c|c|c|c|c|c|c|c|c|}
\hline \multirow[b]{3}{*}{ Age } & \multirow[b]{3}{*}{ AEZ } & \multicolumn{14}{|c|}{ Frequency meal time } \\
\hline & & \multicolumn{2}{|l|}{ One } & \multicolumn{2}{|l|}{ Two } & \multicolumn{2}{|l|}{ Three } & \multicolumn{2}{|l|}{ Four } & \multicolumn{2}{|l|}{ Five } & \multicolumn{2}{|l|}{ Six } & \multicolumn{2}{|l|}{ Total } \\
\hline & & NRP. & $\%$ & NRP & $\%$ & NRP & $\%$ & NRP & $\%$ & NRP & $\%$ & NRP & $\%$ & NRP & $\%$ \\
\hline & Dega & 3 & 6 & 35 & 70 & 12 & 24 & & & & & & & 50 & 100 \\
\hline \multirow[t]{4}{*}{$>14$ years } & Woina Dega & 2 & 2 & 72 & 72 & 26 & 26 & & & & & & & 100 & 100 \\
\hline & Kolla & & & 23 & 46 & 27 & 54 & & & & & & & 50 & 100 \\
\hline & Total & 5 & 2.5 & 130 & 65 & 65 & 32.5 & & & & & & & 200 & 100 \\
\hline & Dega & 1 & 2.1 & 22 & 45.8 & 23 & 47.9 & 2 & 4.2 & & & & & 48 & 100 \\
\hline \multirow[t]{4}{*}{ 5-14 years } & Woina Dega & & & 50 & 58.1 & 29 & 33.7 & 3 & 3.5 & 2 & 2.3 & 2 & 2.3 & 86 & 100 \\
\hline & Kolla & & & 13 & 30.9 & 25 & 59.5 & 2 & 4.8 & 1 & 2.4 & 1 & 2.4 & 42 & 100 \\
\hline & Total & 1 & 0.6 & 85 & 48.3 & 77 & 43.8 & 7 & 3.9 & 3 & 1.7 & 3 & 1.7 & 176 & 100 \\
\hline & Dega & & & 6 & 20.7 & 16 & 55.2 & 3 & 10.3 & 2 & 6.9 & 2 & 6.9 & 29 & 100 \\
\hline \multirow[t]{3}{*}{$<5$ years } & Woina Dega & & & 14 & 22.6 & 32 & 51.6 & 4 & 6.5 & 10 & 16.1 & 2 & 3.2 & 62 & 100 \\
\hline & Kolla & & & 9 & 20 & 28 & 62.2 & 4 & 8.9 & 3 & 6.7 & 1 & 2.2 & 45 & 100 \\
\hline & Total & & & 29 & 21.3 & 76 & 55.9 & 11 & 8.1 & 15 & 11 & 5 & 3.7 & 136 & 100 \\
\hline
\end{tabular}

Source: Based on Field Survey; NRP = Number of respondents

It is obvious that chronic hunger/famine reduces labor productivity and increases vulnerability to diseases. As table (Table 4) revealed that poor nutrition was among the major constraints of labor productivity in the study area. Amongst the 200 respondents $65 \%$ of adults ate only twice a day (mornings and evenings). This occurred under normal and good harvesting years. The frequency of meals reduced to one or more during drought and famine seasons and years. In 
terms of agro-ecology, two meals per day were more common in Woina Dega $72 \%$ and Dega $70 \%$ whereas in Kolla $46 \%$. About $54 \%$ of the peasants residing in Kolla zone ate a standard three meal a day compared to one-fourth of them in Dega and Woina Dega local districts.

The pattern of food intake among children between 5 and 14 years was not upto the standard. Though most parents realized the additional nutritional needs of their children, they have no capacity to fulfill them. The nutritional problem was even more dramatic in the case of children aged below 5 years, who have access to only two meals per day excluding the sucking of milk from their mothers. The nutrition/food crisis was much more evident if one looks at the dietary composition of meals that were taken by people (Table 4).

Extremely poor about $27 \%$ consumed roasted cereal (kollo/nifro) or bread (kita) without more protein sauce (wot) even in good harvesting seasons. In the case of Dega area, both of them accounted for $34 \%$ due to the absence of belg rain in the last three to four consecutive years. It was ironic to note that bread (injera), which used to be the norm than exception in the study area, has gradually became a luxury that was not always available/affordable. The intermediate poor $(63.5 \%)$ and the rich farmers $(9.5 \%)$ consumed injera with wot. The latter supplemented it with roasted cereals (kollo/nifro), breads and other types of food.

The Chi-Square test shows that there is homogeneity with regards to (the composition of meals were taken by people) among the responses gathered from Dega, Woina Dega and Kolla agro-climatic zones (Table 5).

Table 5. Dietary composition of meals by agro-ecological zone.

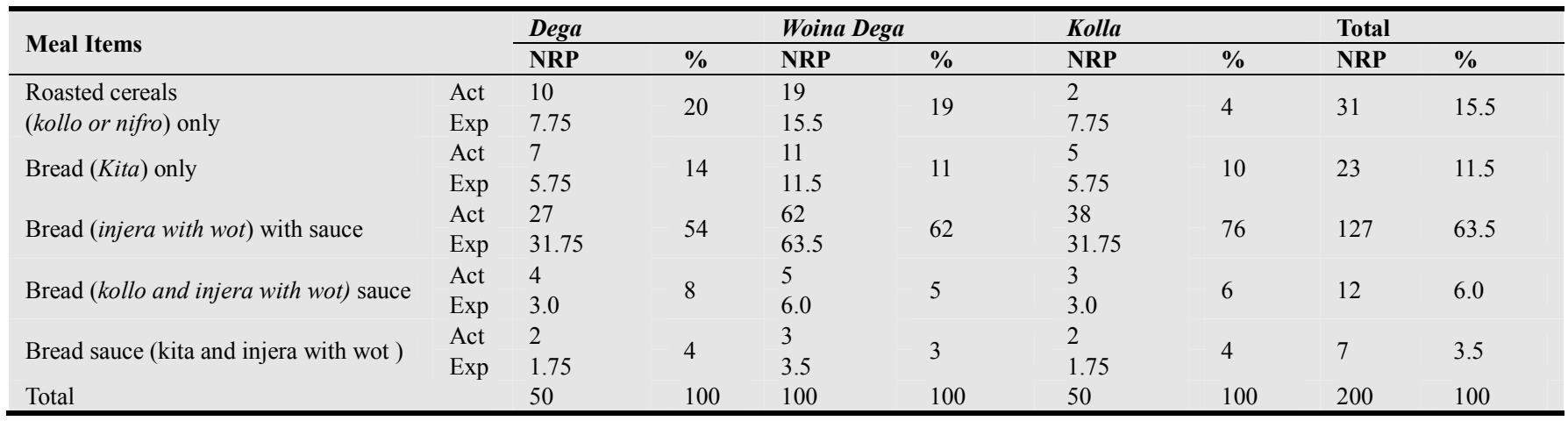

Source: Based on Field Survey $\chi 2=8.72 ; \mathrm{CV}=15.51 ; \mathrm{p}=0.05 ; \mathrm{df}=8 ; \mathrm{act}=$ actual; $\exp =\operatorname{expected}$

\subsubsection{Vulnerability and Food Insecurity}

In this part, attempts would be made to fill some of the gaps by examining the differential impact of drought on farm households in Ethiopia in general and Delanta Dawunt District in particular. The effects of drought on richer and poorer households could be defined by their net annual income. The key questions that were raised during the course of the survey had been whether every household in the community is equally affected by drought and what households do to mitigate the effect of drought and associated food insecurity. To the effect, information on production, income, and food consumption was collected and disaggregated by agro-ecological zone (highland and lowland), sex, and socio-economic strata.

The effects of drought on richer and poorer households could be defined by their net annual income. The key questions that were raised during the course of the survey had been whether every household in the community is equally affected by drought and what households do to mitigate the effect of drought and associated food insecurity. To the effect, information on production, income, and food consumption was collected and disaggregated by agro-ecological zone (highland and lowland), sex, and socio-economic strata.

In the 1990s', the guiding principles for understanding vulnerability to famine and food insecurity shifted from the global to local levels. As a result, practitioners at all levels of decision-making have shifted their attention from national food stock to individual household reserves [24]. The case study from Delanta Dawunt District had revealed that food insecurity complex were heterogeneous between climatic zones and local districts (Table 6) shows this reality in Delanta Dawunt. As Table 6 depicts that about $20 \%$ of the sampled households said that people were equally affected by drought and are equally vulnerable and food insecure. The majority of the respondents' $80 \%$, however, stated that not all people were equally affected by drought and not all households were equally food insecure and vulnerable. Most of the time poor peasants and landless farmers were much more exposed to drought and famine. Conversely, the relatively better-off households have the capacity and resources to mitigate and withstand the worst effects of drought.

The Chi-Square test was shown that there were significant differences among the three agro-ecological zones with regards to the subjects in question Kolla agro-ecological zone (86\%) having a higher proportion than Woina Dega (84\%) and Dega $(66 \%)$ climatic zones. The question comes why are their differences? As information considered from various sectorial offices vis-à-vis disaster prevention commission (DPPC) and Wereda Agriculture Office Report [13], Wereda Education Office Report (WEOR), Wereda Health Office Report (WHOR) and the sampled respondents, the reasons were shortage of rainfall, and occurrence of plant disease and insects were much more in Kolla agro-ecological area than in Dega and Woina 
Dega areas. Due to these and other similar reasons, the people who were living in Kolla area were more vulnerable and food insecure than others. The District was characterized by high rate of land degradation, low agricultural inputs, poor technology, and high population pressure, which all have contributed to increases in vulnerability to natural disasters and food shortage.

The researcher also raised one question to see frequency of meals consumed by all household members. It was found out that over $90 \%$ of women have a lower frequency of meal intake compared to $26 \%$ of men and $22 \%$ of children. The reason for women's lower food consumption than others has something to do with prioritization women normally first the family or give priority for small children, husbands and others feed than themselves. As a result, they were left with fewer amounts of food or none. In line with the feeding system of the family members, Dankelman and Davidson [25] supported this idea when they stated that women in many cultures were often the last in the family who ate, and they took less than other family members do. The other reasons for women's vulnerability to famine were breast-feeding, pregnancy and load of work. All these contributed to women's much more vulnerable situation and food insecurity. The villagers of Delanta Dawunt say; "We used to be happy with our lives, satisfied with what we had, food and drink was also in excess. All of a sudden we were caught by drought, unable to acquire little food even for a taste.

Table 6. Degree of reliability of households.

\begin{tabular}{|c|c|c|c|c|c|c|c|c|c|c|}
\hline & & \multirow{6}{*}{$\begin{array}{l}\text { Atc. } \\
\text { Exp. } \\
\text { Atc. } \\
\text { Exp. }\end{array}$} & \multicolumn{2}{|l|}{ Dega } & \multicolumn{2}{|c|}{ Woina Dega } & \multicolumn{2}{|l|}{ Kolla } & \multicolumn{2}{|c|}{ Total } \\
\hline \multirow{5}{*}{$\begin{array}{l}\text { Are people equally affected by } \\
\text { drought and equally vulnerable and } \\
\text { food insecure? }\end{array}$} & \multirow{3}{*}{ Yes } & & NRP & $\%$ & NRP & $\%$ & NRP & $\%$ & NRP & $\%$ \\
\hline & & & 17 & 34.0 & 16 & 16.0 & 7 & 14.0 & 40 & 20.0 \\
\hline & & & 10 & & 20 & & 10 & & & \\
\hline & No & & $\begin{array}{l}33 \\
40\end{array}$ & 66.0 & $\begin{array}{l}84 \\
80\end{array}$ & 84.0 & $\begin{array}{l}43 \\
40\end{array}$ & 86.0 & 160 & 80.0 \\
\hline & Total & & 50 & 100 & 100 & 100 & 50 & 100 & 200 & 100.0 \\
\hline
\end{tabular}

Source: Based on Field Survey $\chi 2=8.5 ; \mathrm{C} . \mathrm{V}=5.99 ; \mathrm{p}=0.05 ; \mathrm{df}=2$

\subsubsection{Coping Mechanisms}

Famine can occur even when some food is available. Food entitlements matter and are critical in an analysis of food security [26]. Communities were not passive in the face of production failure that could lead to famine. They were responding in a variety of ways. Examples of such coping strategies include collection of wild foods, migration in search of employment, reduction in consumption, sale of possessions or productive assets. Coping strategies could be difficult to identify, particularly in areas where diversification of activities is fundamental to livelihood. In the study area, many farmers derived income from one or two sources to augment their low level of income.

Some of the coping strategies were used by the peasants during famine (food insecurity) period in Delanta Dawunt District (Table 7). Amongst the total respondents half of them have reduced quantity of food and frequency of meals times they consumed as a coping strategy. Other strategies followed by the household include, change to lower quality of food (47\%), borrowing crops and/or money from others (46\%) and the searching for food-aid from either government or NGOs (39\%). Coping mechanisms such as sending family members to join distant relatives, eating wild plants (animals) and migrating to other places had been used by 12,11 and $9 \%$ of the respondents, respectively. Wild plants vis-à-vis getin and sama were commonly consumed in Dega (20\%), Kolla (6\%) and Woina Dega $(8 \%)$ areas (Table 7$)$.

Table 7. Coping mechanisms in time of food scarcity.

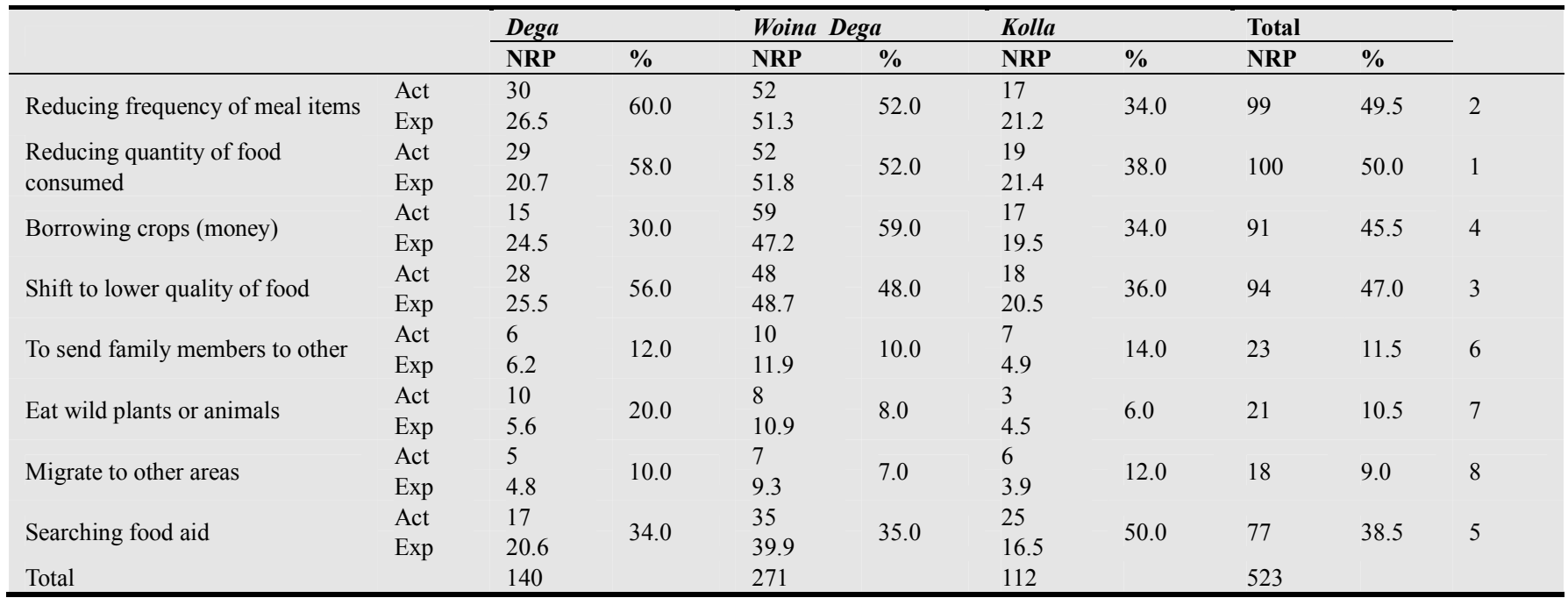

Source: Based on Field Survey $\chi 2=25.65 ; \mathrm{C} . \mathrm{V}=23.6 ; \mathrm{p}=0.05 ; \mathrm{df}=12 ; \mathrm{NRP}=$ Number of respondents 
There seems to be adaptation and adjustment at the cost of sacrificing even basic necessities rather than finding solution and innovative ways to overcome the problems. Key informants recalled that acute famine episodes and serious food shortages began to be experienced in Delanta Dawunt District as of $1972 / 73$. This does not, however, imply that there were no periods of stress before this. The 1972/73 case was much more pronounced and more devastating with farreaching consequences for the livelihood of society. At the time of the survey, massive starvation occurred in the District though no human loss of life has been experienced. The degree of affliction was so extreme that people were forced to consume famine food in the form of wild herbs and roots, a practice that was uncommon for people in the study area. Food insecurity in Delanta Dawunt District could, hence, be attributed to host of factors including, extreme poverty, climatic fluctuations, and rainfall scarcity and dryness in the last thirty years.

The first impacts of droughts were observed in environmental damages and in the reduction of agricultural outputs. With the failure of rains, livestock productivity declines, at first in slows manner and then more rapidly. This was followed by the sickness of older people and children. When a serious hunger set in the breaking-up families were begun. Famine comes at the end of the cycle: when people could not produce their own food and when they no longer have anything of value to sell in exchange for food and when sales of livestock skins and hides, jewelry and/or household goods, local brewing, begging from relatives and friends to secure food were exhausted.

The coping strategies were further examined on the basis of eight commonly performed tasks on agro-ecological basis. Observations were tested by using Chi-Square tests to see whether there is any significant difference among the three agro-climatic areas (Table 7). The calculated value ( $\chi 2$ cal) of 25.65 exceeds the critical value $(\chi 2$ tab) of 23.68 at $95 \%$ confidence level. This shows that a significant difference among the three agro-ecological zones in coping strategies during famine and food insecurity period. In the case of Dega, reducing frequency of meal items, reducing quantity of food consumed and change to lower quality of food accounted for
60,58 and $56 \%$, respectively which was higher than the other two areas, whereas the Kolla zone was searching food-aid to $50 \%$, sending family member to other family (14\%) and migrate to other areas $(12 \%)$ was higher than the other zones.

\subsubsection{Challenges Related to Infrastructure and service Provisions}

The people of Delanta Dawunt suffered from food shortage and famines mainly due to the agricultural methods were backward, the rainfall was erratic, and the landholdings were small and infertile. Over and above these, when children grew and married they shared the small plot of family land to sustain their new family. This made subsistence life at risk and livelihood more challenging for the whole family members.

Chronic poverty coupled with the intermittent drought intensifies the problem of women who suffered more from malnutrition because they often gave priority to feed other members of the family. Women are the backbones of social and economic conditions in rural Ethiopia in general and the study area in particular. However, the existence of different taboos and recurrent famines made their lives much more complicated.

The first sets of social challenges in Delanta Dawunt District were transport (86\%), food quantity and quality (84.5), water (80\%) and health $(71.5 \%)$ due to the shortage of health facilities and related provisions. The other set of social constraints were fuel shortage due to deforestation (54\%), lack of agricultural inputs due to lack of transportation $(44.5 \%)$ and lack of education services (26\%) especially junior secondary, secondary, preparatory, vocational and technical schools. These were the main constraints to socialeconomic developments (Table 8). When we looked at women respondents alone, food quality and quantity (74\%), water $(73 \%)$, health problem $(67 \%)$ lack of transportation $(66 \%)$ and fuel-wood (47.5\%). In addition, there were some other problems, for example, physical disability due to vetch (guaya) that also impeded productivity. It was a great problem in Delanta Dawunt District in 1997/98 where about 900 people were affected by vetch. It was much higher in Woina Dega sampled local districts than others.

Table 8. Lack of access to basic infrastructure and resources.

\begin{tabular}{|c|c|c|c|c|c|c|c|c|c|}
\hline & Dega & & Woin & & Kolla & & Total & & Rank \\
\hline & NRP & $\%$ & NRP & $\%$ & NRP & $\%$ & NRP & $\%$ & \\
\hline Food (quantity and quality) & 47 & 94 & 87 & 87 & 35 & 70 & 169 & 84.5 & 2 \\
\hline Lack of health service & 34 & 68 & 62 & 62 & 46 & 92 & 142 & 71 & 4 \\
\hline Fuel-wood shortage & 35 & 70 & 51 & 51 & 22 & 44 & 108 & 54 & 5 \\
\hline Lack of education service & 10 & 20 & 28 & 28 & 14 & 28 & 52 & 26 & 7 \\
\hline Lack of transportation & 43 & 86 & 89 & 89 & 40 & 80 & 172 & 86 & 1 \\
\hline Lack of agricultural inputs & 23 & 46 & 47 & 47 & 19 & 38 & 89 & 44.5 & 6 \\
\hline Water (quantity and quality) & 45 & 90 & 73 & 73 & 42 & 84 & 160 & 80 & 3 \\
\hline
\end{tabular}

Source: Based on Field Survey; NRP $=$ Number of respondents

\subsection{Gender Division of Labor in Sustain Food Security}

The sexual division of labor by task cannot be fully understood without knowing how women and men within the household differ in their agricultural information and services. In order to understand and analyze the gender division of labor, that is the allocation of tasks between males and 
females, and the household activities can be categorized into two groups, namely, production (outside in field) and domestic activities. The former category includes the entire range of activities associated with the field work and animal raring (farming activities). The later is the daily maintenance of the household works including food preparation, family care, fetching water and fuel-wood.

The flexibility or rigidity of the sexual division of labor can be ascertained at the community or household levels through a combination of direct observation (if time permits seasonal sampling survey), reliance on informants and structured interviews with individuals. Rural women generally work much longer hours than men. However, it is difficult to tell the exact time spent by women in agricultural activities. From the survey made in the study area, the author of this paper has come to understand that women spend more time in seed-bed preparation, harvesting of crops, weeding, transporting, storage preparation, etc. These activities may be done either individually or through groups (wonefel or debbo). Women also prepare food and drinking water for the participants during the wonfel or debbo activities.

In Delanta Dawunt, the expected and the most important occupation of the family members aged 10 years and above is farming. Employment outside agriculture is almost nonexistent in the District. It is a key asset for subsistence farmers in the District. The division of labor in the area is traditional meaning that some tasks are reserved for men and others for women. Children, depending on their sex, tend to follow their parents' occupations and learn from them. There is a clear gender and age based division of labor in crop production, animal husbandry, and household tasks (Table 9).

Table 9. Gender division of labor in agriculture and household activities

\begin{tabular}{|c|c|c|c|c|c|c|c|c|}
\hline \multirow{2}{*}{ Activity } & \multicolumn{2}{|c|}{ Women } & \multicolumn{2}{|l|}{ Men } & \multicolumn{2}{|l|}{ Both } & \multicolumn{2}{|c|}{ Children } \\
\hline & NRP & $\%$ & NRP & $\%$ & NRP & $\%$ & NRP & $\%$ \\
\hline \multicolumn{9}{|l|}{ Crop production } \\
\hline Land preparation & 0.0 & 0.0 & 182.0 & 91.0 & 11.0 & 5.5 & 7.0 & 3.5 \\
\hline Ploughing & 0.0 & 0.0 & 170.0 & 85.0 & 16.0 & 8.0 & 14.0 & 7.0 \\
\hline Sowing & 0.0 & 0.0 & 172.0 & 86.0 & 0.0 & 0.0 & 28.0 & 14.0 \\
\hline Carrying farm tools & 0.0 & 0.0 & 176.0 & 88.0 & 14.0 & 7.0 & 10.0 & 5.0 \\
\hline Weeding & 35.0 & 17.5 & 47.0 & 23.5 & 106.0 & 53.0 & 12.0 & 6.0 \\
\hline Collecting crops to field floor & 34.0 & 17.0 & 47.0 & 23.5 & 101.0 & 50.5 & 18.0 & 9.0 \\
\hline Transport yields to home & 0.0 & 0.0 & 180.0 & 90.0 & 0.0 & 0.0 & 20.0 & 10.0 \\
\hline Threshing ground preparation & 10.0 & 5.0 & 13.0 & 6.5 & 165.0 & 82.5 & 12.0 & 6.0 \\
\hline Storage container preparation & 183.0 & 91.5 & 17.0 & 8.5 & 0.0 & 0.0 & 0.0 & 0.0 \\
\hline Storing process & 166.0 & 83.0 & 15.0 & 7.5 & 19.0 & 9.5 & 0.0 & 0.0 \\
\hline Keeping crops from wild life & 25.0 & 12.5 & 38.0 & 19.0 & 64.0 & 32.0 & 73.0 & 36.5 \\
\hline Animal husbandry & & & & & & & & 0.0 \\
\hline Feeding & 25.0 & 12.5 & 92.0 & 46.0 & 36.0 & 18.0 & 47.0 & 23.5 \\
\hline Milking cows & 64.0 & 32.0 & 86.0 & 43.0 & 37.0 & 18.5 & 13.0 & 6.5 \\
\hline Milk processing & 165.0 & 82.5 & 0.0 & 0.0 & 0.0 & 0.0 & 35.0 & 17.5 \\
\hline Care of new born & 104.0 & 52.0 & 26.0 & 13.0 & 31.0 & 15.5 & 39.0 & 19.5 \\
\hline Herding & 11.0 & 5.5 & 28.0 & 14.0 & 13.0 & 6.5 & 148.0 & 74.0 \\
\hline Household work & & & & & & & & 0.0 \\
\hline Food processing & 192.0 & 96.0 & 0.0 & 0.0 & 0.0 & 0.0 & 8.0 & 4.0 \\
\hline Fetching water & 172.0 & 86.0 & 12.0 & 6.0 & 0.0 & 0.0 & 16.0 & 8.0 \\
\hline Collecting fuel-wood & 149.0 & 74.5 & 13.0 & 6.5 & 15.0 & 7.5 & 23.0 & 11.5 \\
\hline Grinding grains & 194.0 & 97.0 & 0.0 & 0.0 & 0.0 & 0.0 & 6.0 & 3.0 \\
\hline Cleaning household floor & 180.0 & 90.0 & 0.0 & 0.0 & 0.0 & 0.0 & 20.0 & 10.0 \\
\hline Washing dish \& others & 187.0 & 93.5 & 0.0 & 0.0 & 0.0 & 0.0 & 13.0 & 6.5 \\
\hline Maintenance cloth & 108.0 & 54.0 & 0.0 & 0.0 & 92.0 & 46.0 & 0.0 & 0.0 \\
\hline Care of family & 92.0 & 46.0 & 24.0 & 12.0 & 72.0 & 36.0 & 12.0 & 6.0 \\
\hline
\end{tabular}

Source: Based on Field Survey; NRP = Number of respondents

As manifested in Table 9, men solely performed 90, 88, 86 and $85 \%$ transport yield to home, carrying farm tools sowing and ploughing, respectively while women assisted their husbands in such activities. For example, women cover the seed with soil when the man sows, pull horses when ploughing is done, clear waste from the field, prepare threshing field, etc. Both men and women are also working equally in weeding (53\%), harvesting (50\%), collecting and transporting grains (crops) to threshing fields (51\%) and trashing ground preparation (83\%). On the other hand, adult females (women) performed all most all household activities and $92,83,63$, and $52 \%$ of storage container preparation, storing and milk processes, barn cleaning and care of new born animals, respectively. In all these activities children assist their mothers, particularly female children and male children mostly herd animals, bird scared and crops protect from wild life.

The situation of women in general indicates that they carried out the heaviest burden of family life responsibility, which includes feeding, housing, clothing, and breadwinner sharing. They are doing all these things with a backward technology where implements and tools are the most primitive. On top of the crop production, and livestock raising activities, women are responsible for all household 
tasks. They carry out full responsibility for bearing and caring children, nurturing and breast- feeding them after birth Rural women lie at the heart of loath ensuring livelihood and attaining food security. They have always been made the invisible workforce and the unacknowledged backbone of the family economy. Generally speaking, women do most of the monetized and non-monetized economies.

\section{Conclusions}

As the study has shown, women carried out full responsibility for bearing and caring children, nurturing and breast- feeding them after birth. Rural women lie at the heart of loath ensuring livelihood and attaining food security. They had always been made the invisible workforce and the unacknowledged backbone of the family economy. Generally speaking, women do most of the monetized and nonmonetized economies.

However, their crucial roles in the attainment of sustainable livelihood food security have been downsized and belittled due to their marginal status. Their roles have been relegated to a secondary status within the household and the community at large. Women were unlikely to get firsthand information about new technology and farm inputs. Even female household heads got indirect information simply because they were excluded from attending meetings and were nowhere in the leadership of peasants' associations. All these factors were hindered women's full participation in any activities and resource control. If women are empowered and their roles are recognized by the society, there is a good possibility of lessening vulnerability and improving rural livelihoods in the study area and other rural localities in Ethiopia. This could be one good way by which food security could be attained in Delanta Dawunt District.

\section{Acknowledgements}

The authors are thankful to Ministry of Education for its financial support, and Addis Ababa University to give the chance of learning. The authors are also greatly acknowledged for Andarge Asmare, Tesfaye Wolde and othercolleagues to support during data collection.

\section{References}

[1] Pimental, D. (1993). Overview: World soil erosion and conservation. Cambridge: Cambridge University Press.

[2] Sara, M. (1998). Muslim women in Ethiopia: Their political participation and status in the community. Unpublished Essay, Addis Ababa University.

[3] UN (1991). Population growth and position of women in the family. In: Hutter, Mark (ed.). The changing family United Nations Development Fund. New York: United Nations Press.

[4] Bandarage, A. (1997). Women, Population and Global Crisis: Political-Economic Analysis. London and New Jersey: Zed Books.
[5] FAO. (1995). Women, agriculture and rural development: A synthesis report of the African Region. United Nations University Press.

[6] DFID (British Department for International Development). (2002). Sustainable urbanization: Achieving Agenda 21. UN Habitat and Department for International Development Publishers.

[7] FAO. (1987). Women in Africa food production and food security. In: Gittenger J. Price et al (eds.). Food Policy Integrating Supply, Distribution and Consumption. London and Baltimore: Hopkins University Press.

[8] FAO. (1996). Report for the world food summit. Rome: Italy, 13-17 November.

[9] Zenebework, T. (2003). Women and land right in third world: The case of ethiopia. In: Wanyeki, L. Muthoni (ed.). Women and land in Africa: Culture, religion realizing women's rights. London and New York: Zed Books Ltd.

[10] Stockard, J. (1997). Sociology: Discovering society. USA: Wadsworth Publishing Company.

[11] Mulunesh, W.M. (2001). Gender sustainable livelihood and food security in rural Ethiopia. In: YaredAmare (ed.). Food security and sustainable livelihood in Ethiopia. Proceedings of the Symposium of the Forum for Social Studies, Addis Ababa, March 10-11, 2000.

[12] Tesfaye, Z. and Debeb, H. (1995). Food security: A situation analysis. In: Mulate D. et al (eds.). Food security, nutrition, and poverty alleviation in Ethiopia: Problems and Prospect. Proceedings of the Inaugural and First Annual Conference of the Agricultural Economics Society of Ethiopia, Addis Ababa, 8-9 June.

[13] WAOR. (2004). Delanta Dawunt Wereda agriculture and natural resource development department office report. Wegeltena, Ethiopia.

[14] Getahun, A. (1984). Stability and instability of mountain ecosystems in Ethiopia. Mountain Research and Development, 4: 39-44.

[15] Mohr, P. A. (1971). The Geology of Ethiopia. Haile Sellassie I University press. Addis Ababa, Ethiopia.

[16] Dereje, A., P. Barbey, B. Marty, L. Reisberg, Y. Gezahegn and R. Pik, (2002). Source, genesis and timing of giant ignimbrite deposits associated with Ethiopian continental flood basalts. Elsevier Science Ltd, GeochimicaetCosmochimicaActa, 66: 1429-1448.

[17] FAO/UNDP. (1984). Training of man power for agricultural and rural development in Africa. ARC/84/3; Rome: Italy.

[18] CSA. (1994). Population and Housing Census of Ethiopia:The Results for Amhara Region. Addis Ababa. Vol.1.

[19] WEOR. (2004). Delanta Dawunt WeredaEducation Department Office Report. Wegeltena, Ethiopia.

[20] WHOR. (2004). Delanta Dawunt WeredaHealth Department Office Report. Wegeltena, Ethiopia.

[21] Daniel, H. (1984). The legal status of rural women in Ethiopia. Working Paper Presented at the National Workshop on Women Agricultural Developments.Awassa, Ethiopia, 26 June - 2 July, 1983. 
[22] World Bank, (1998). Implementing the Ethiopian national policy for women institution and regulatory issues. World Bank: Oxford University Press.

[23] ILO (International Labor Organization). (1997). Ruralwomen in micro-enterprise development training manual and programme for extension workers. Second Impression. Geneva: Switzerland.
[24] Stephen, L.J. (2002). Vulnerability and food insecurity in Delanta Dawunt District. Unpublished paper.

[25] Dankelman, Irene and Davidson, Joan. (1997). Women and environment in the third world: Alliance for the future. London: Earthscan Publication Ltd. in associate with IUCN.

[26] Sen, A.K. (1981). Poverty and Famines: Essay on entitlements and deprivation. London: Clarendon Press. 